Brit. J. vener. Dis. (1963), 39, 160.

\title{
TREATMENT OF ACUTE GONORRHOEA WITH SINGLE INJECTIONS OF CHLOROMYCETIN SUCCINATE*
}

\author{
BY \\ R. R. WILLCOX \\ St. Mary's Hospital, London W.2
}

With the emergence of strains of gonococci less sensitive than formerly to antibiotics, particularly penicillin and streptomycin, and because some patients exhibit sensitivity to them, there is a need for alternative antibiotics. However, penicillin is still generally agreed to be the antibiotic of choice for the routine treatment of gonorrhoea.

The numerous alternatives available include the tetracyclines, chloramphenicol, erythromycin, spiramycin, and oleandomycin, but these are open to the objection that they are generally given by mouth. Not only do patients vary in their powers of absorption of orally-administered drugs but those with venereal diseases are notoriously unreliable in taking their medicines at the times and in the doses required. The danger also remains that unused tablets may be reserved for self-medication at a later date or may even be sold in the "black market". Most of these difficulties can be overcome if single doses are administered under supervision in the clinic, but large expensive doses are usually required and it is therefore preferable to give them by injection.

Of the injectable alternatives, streptomycin sulphate is the cheapest and has been the most used, but increasing failure rates to streptomycin as to penicillin are being noted in some areas (Willcox and Mallett, 1962). Strains of gonococci showing relative insensitivity to penicillin are frequently resistant to streptomycin also, and with the latter antibiotic complete resistance is the rule.

The tetracyclines, usually given by mouth as the next best alternative, cannot yet satisfactorily be given in the doses required in a single injection. Although cures can be obtained by single injections of $0.5 \mathrm{~g}$., the preparations are poorly tolerated locally and local pain, which often persists for some hours, is complained of by approximately one half of patients (Willcox, 1960).

* Received for publication May 6, 1963.
The newest alternative, actinospectacin (Trobicin), has given good results in single injections particularly in patients in whom penicillin has failed (Willcox, 1962), but this antibiotic is not yet available commercially.

Chloromycetin succinate has been available, for injection, for a number of years, but has not been widely used in the treatment of gonorrhoea because of the haemopoietic side-effects reported to follow prolonged dosage. This drug (chloramphenicol sodium succinate) is the sodium salt of the monosuccinic ester of chloramphenicol; it is supplied in rubber-capped vials containing the ester as a freezedried powder equivalent to $1 \mathrm{~g}$. chloramphenicol, and is prepared for injection by the addition of 2 to $3.8 \mathrm{ml}$. of an aqueous or saline diluent. It was felt worthwhile to try this preparation in the treatment of gonorrhoea and to compare the results with those obtained with other antibiotics.

\section{Material}

53 male patients with uncomplicated acute gonorrhoea have been treated with single intramuscular injections of chloromycetin succinate: 25 were Negroes ( 22 from the West Indies, two from West Africa and one from East Africa), eight were born in the United Kingdom, seven in Eire, three in India, two in Pakistan, and one each in Austria, Ceylon, France, Germany, New Zealand, Portugal, the Seychelles, and South America. Their average age was $27 \cdot 5$ years (range 19 to 56); thirteen were married and forty were single.

Only twelve patients denied a previous venereal incident, the remaining 41 having had no less than 89 previous attacks of gonorrhoea, thirty of non-gonococcal urethritis, one of herpes genitalis, and one of epididymitis. One was a diabetic. Of the 121 previous incidents, 74 (57 of gonorrhoea) had involved the Negro patients who thus averaged three previous incidents each compared with $1 \cdot 7$ each for the remainder. 


\section{Clinical Findings}

The discharge had been present before treatment for 1 to 3 days in 34 patients, for 4 to 7 days in sixteen, for 8 to 14 days in two, and for 22 to 28 days in one. Dysuria was reported by 41 patients.

The disease had apparently been caught from strangers (including prostitutes) in 28 cases, from a friend in nineteen, from the wife in four, and from another man in one; one patient denied exposure.

The apparent incubation period was 1 to 3 days in sixteen, 4 to 7 days in eighteen, 8 to 14 days in nine, 15 to 21 days in three, and 22 to 28 days in one; it was unknown in six.

The Wassermann and VDRL (or Kahn) reactions were both negative in 48 patients, and both positive in two West Indian patients; the Wassermann reaction was negative and the other test positive in three cases (one West Indian, one South American, and one born in the United Kingdom). Doubtless in some cases sero-positivity was due to previous yaws. The gonococcal complementfixation reaction was negative in eight sera tested.

\section{Case Management}

In all cases a urethral smear was taken before treatment and the gonococcus identified by Gram's stain. The chloromycetin succinate was then given intramuscularly in single $1 \mathrm{-g}$. doses. The patients were seen again after 2 to 3 days and it was planned they should attend again at approximately 7, 14, 28, 56 , and 90 days after treatment. At each posttreatment visit the urethra was examined for discharge, and a smear was taken if a discharge was present. The urine was examined for haze and threads. It was intended that at least one examination of the prostatic secretion should be made during surveillance and that, unless there were other indications, serum tests for syphilis were to be made at the time of therapy and again after 3 months. By no means all patients attended at the times instructed, but sufficient time has elapsed for a minimum followup of at least 1 to $4 \frac{1}{2}$ months to be obtained for all patients.

\section{Results}

The follow-up and results obtained are shown in Table I.

TABLE I

RESULTS OF TREATING 53 MALE CASES OF GONORRHOEA WITH $1 \mathrm{~g}$. CHLOROMYCETIN SUCCINATE

\begin{tabular}{|c|c|c|c|c|c|c|}
\hline \multirow{2}{*}{\multicolumn{2}{|c|}{$\begin{array}{l}\text { Length of } \\
\text { Follow-up }\end{array}$}} & \multirow{2}{*}{$\begin{array}{c}\text { No. } \\
\text { Fol- } \\
\text { lowed }\end{array}$} & \multicolumn{4}{|c|}{ Result } \\
\hline & & & $\begin{array}{l}\text { Satis- } \\
\text { factory }\end{array}$ & $\begin{array}{c}\text { Non- } \\
\text { gonococcal } \\
\text { Infection }\end{array}$ & $\begin{array}{c}\mathrm{Re}_{-} \\
\text {infection }\end{array}$ & Failed \\
\hline \multicolumn{2}{|c|}{$\begin{array}{r}0 \\
1-3 \text { days } \\
4-7 \text { days } \\
8-14 \text { days } \\
15-21 \text { days } \\
22-28 \text { days } \\
1-2 \text { mths } \\
2-3 \text { mths }\end{array}$} & $\begin{array}{r}53 \\
44 \\
32 \\
26 \\
18 \\
8 \\
7 \\
1\end{array}$ & $\begin{array}{r}71 \\
3 \\
4 \\
6 \\
1 \\
4 \\
-\end{array}$ & $\begin{array}{r}\overline{-} \\
2 \\
2 \\
1 \\
1 \\
-\end{array}$ & $\begin{array}{l}\overline{-} \\
1 \\
2 \\
\frac{2}{1} \\
1\end{array}$ & $\begin{array}{l}\overline{1} \\
\overline{1} \\
\bar{z} \\
=\end{array}$ \\
\hline \multirow{2}{*}{ Total } & No. & 44 & 29 & 6 & 7 & 2 \\
\hline & $\begin{array}{l}\text { Per } \\
\text { cent. }\end{array}$ & $100 \cdot 0$ & $65 \cdot 9$ & $13 \cdot 6$ & 15.9 & $4 \cdot 5$ \\
\hline
\end{tabular}

Of 53 patients treated, 44 were followed and the status was satisfactory at last visit in 29 . Six patients required treatment for non-gonococcal infection and seven for presumed re-infection, and two were considered to be treatment failures $(4 \cdot 5$ per cent. of those followed).

No satisfactory criteria exist to distinguish relapse from re-infection apart from a history of further sexual exposure; this was admitted by all seven men listed as presumed re-infections, in one case with the original consort who had not then been treated.

Comparison of Results in Negro Patients and Others.-The results obtained in Negroes and in others are compared in Table II. Both failures occurred in the non-Negro group, but no less than six of the seven presumed re-infections and four of the six subsequent non-gonococcal infections occurred in Negroes who, as their previous experience of venereal disease suggests, are more prone to re-infection than men of other races, at any rate in London.

TABLE II

RESULTS IN NEGROES AND OTHERS

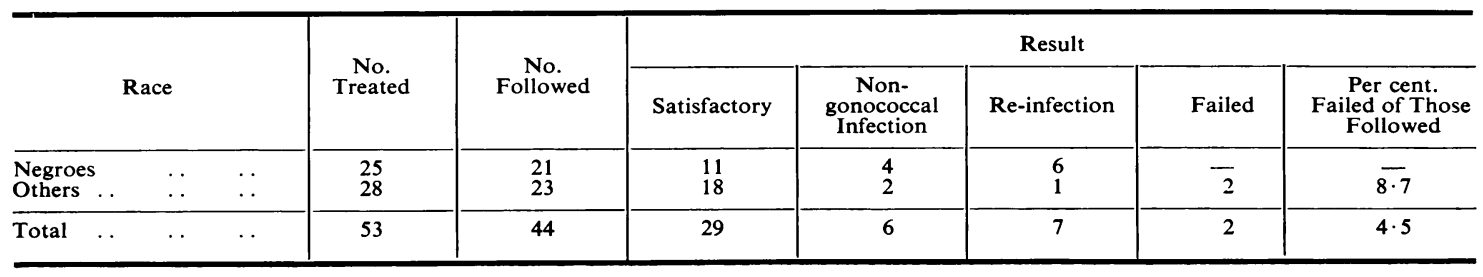


Comparison of Chloromycetin Succinate with Other Injectable Antibiotics.-The results personally obtained with single injections of other antibiotics are listed for both Negro and other patients in Table III. These series were treated in similar conditions, and there was the same difficulty in obtaining an adequate follow-up and in distinguishing relapse from re-infection. They include one series treated with single injections of 1.2 mega units aqueous procaine penicillin approximately 3 months before the series here described. The results then obtained were apparently worse than those of a series treated with the same dose of penicillin 2 years previously, which is also included.

In most instances Table III shows a tendency towards higher apparent failure rates in Negroes than in other patients, doubtless because some re-infections have been unwittingly included. This indicates, however, that the present results obtained with chloromycetin succinate compare very favourably with those obtained with other injectable antibiotics.

\section{Experience with 2 g. Chloromycetin Succinate}

In addition to the series reported using $1 \mathrm{~g}$. chloromycetin succinate, single doses of $2 \mathrm{~g}$. were given to three other patients with gonorrhoea. One patient defaulted, in one failure was noted at 9 days, and the last was observed to be satisfactory on seven subsequent occasions over a period of 3 months.

\section{Tolerance of the Drug}

The chloramphenicol succinate was less well tolerated locally than penicillin. Local pain was complained of without prompting by eight patients, and in two of them was very severe. In four of these eight cases pain was associated with faintness and in one faintness occurred without local pain.

The initial local reactions were of the same severity as had been noted with intramuscular tetracycline but appeared to pass off more quickly.

\section{Summary}

The need is discussed for an injectable alternative to penicillin and streptomycin in the treatment of gonorrhoea in patients failing to respond to these antibiotics or allergic to them.

53 male patients with uncomplicated acute gonorrhoea were treated with single injections of $1 \mathrm{~g}$. chloromycetin succinate. Among $\mathbf{4 4}$ followed, there were two failures $(4.5$ per cent. of those followed) and seven re-infections. The difficulties in distingui-shing relapse from re-infection are emphasized.

These results compare very favourably with those obtained in similar conditions with other injectable antibiotic preparations, including procaine penicillin, streptomycin sulphate, the tetracyclines, and actinospectacin (Trobicin).

Grateful acknowledgements are expressed to Messrs Parke Davis and Co. Ltd., of Hounslow, Middlesex, for providing the chloromycetin succinate used in this study.

TABLE III

RESULTS OBTAINED WITH OTHER INJECTABLE ANTIBIOTICS

\begin{tabular}{|c|c|c|c|c|c|c|c|c|c|c|c|c|}
\hline \multirow{2}{*}{\multicolumn{4}{|c|}{ Antibiotic }} & \multirow{4}{*}{$\frac{\text { Dose (g.) }}{1 \cdot 4-1 \cdot 6}$} & \multicolumn{4}{|c|}{ Negroes } & \multicolumn{4}{|c|}{ Other Races } \\
\hline & & & & & \multirow{2}{*}{ Treated } & \multirow{2}{*}{ Followed } & \multicolumn{2}{|c|}{ Failed } & \multirow{2}{*}{ Treated } & \multirow{2}{*}{ Followed } & \multicolumn{2}{|c|}{ Failed } \\
\hline & & & & & & & No. & Per cent. & & & No. & Per cent. \\
\hline Actinospectacin ${ }^{1}$ & . & $\ldots$ & $\ldots$ & & 47 & 42 & 5 & $11 \cdot 9$ & 54 & 47 & 2 & $4 \cdot 3$ \\
\hline \multirow{2}{*}{\multicolumn{2}{|c|}{ Tetracycline phosphate ${ }^{2}$}} & \multirow{2}{*}{$\cdots$} & \multirow{2}{*}{$\cdots$} & 0.5 & 31 & 23 & 4 & $17 \cdot 4$ & 31 & 25 & 4 & $16 \cdot 0$ \\
\hline & & & & $0 \cdot 25$ & 8 & 7 & 2 & $28 \cdot 6$ & 14 & 12 & 6 & $50 \cdot \overline{0}$ \\
\hline Oxytetracycline $^{8}$ & $\ldots$ & $\cdots$ & $\ldots$ & $0 \cdot 25$ & 19 & $1 \overline{7}$ & 5 & $29 \cdot \overline{4}$ & 12 & 10 & 3 & $30 \cdot 0$ \\
\hline Pyrrolidine methyl te & racy & & . & $0 \cdot 25$ & 14 & 11 & 4 & $36 \cdot 4$ & 10 & 9 & 2 & $22 \cdot 2$ \\
\hline Streptomycin ${ }^{4} \ldots$ & . & . & . & $1 \cdot 0$ & 132 & 102 & 15 & $14 \cdot 7$ & 92 & 79 & 12 & $15 \cdot 2$ \\
\hline \multirow[t]{2}{*}{ Procaine penicillin ${ }^{5}$} & \multirow[t]{2}{*}{$\cdots$} & \multirow{2}{*}{$\cdots$} & \multirow{2}{*}{$\cdots$} & \multirow{2}{*}{$\begin{array}{c}1 \cdot 2 \\
\text { mega units }\end{array}$} & \multirow{2}{*}{109} & \multirow{2}{*}{82} & \multirow{2}{*}{10} & \multirow{2}{*}{$12 \cdot 2$} & 170 & 125 & 13 & $10 \cdot 4$ \\
\hline & & & & & & & & & $200^{6}$ & 169 & 10 & $5 \cdot 9$ \\
\hline
\end{tabular}

1 Willcox (1962).

2 Willcox (1960).

3 A further fifteen patients of mixed race given $500 \mathrm{mg}$ oxytetracycline had one failure $(7 \cdot 1$ per cent. of those followed).
4 Willcox and Mallet (1962)

5 Recent series of 109 Negroes and 170 others.

- An earlier series of 200 patients of mixed race. 


\section{REFERENCES}

Willcox, R. R. (1960). “Antibiotics Annual, 1959-1960". Antibiotica, New York.

(1962). Brit. J. vener. Dis., 38, 150.

and Mallet, K. J. H. (1962). Acta derm.-venereol. (Stockh.), 42, 195.

La blennorragie aiguë traitée par une seule injection de succinate de chloromycétine

RÉSUMÉ

On a besoin d'un remède administré par injection pour traiter la blennorragie chez les malades qui ne répondent ni à la pénicilline ni à la streptomycine ou qui sont allergiques.

On essaya une seule injection de $1 \mathrm{~g}$. de succinate de chloromycétine chez 53 hommes atteints de blennorragie aiguë simple. Sur 44 cas suivis il y eut deux rechutes $(4,5 \%)$, et sept furent atteints de nouveau. On remarque la difficulté de distinguer les rechutes des ré-infections.

$\mathrm{Ce}$ résultats sont meilleurs que ceux obtenus dans des circonstances semblables avec d'autres antibiotiques données par voie intramusculaire-y compris la pénicilline, le sulfate de streptomycine, les tétracyclines, et l'actinospectacine (Trobicin). 